\title{
Colonial Legacies in Post-Colonial Collections
}

Mary Elizabeth Barber's death on 4 September 1899 went almost unnoticed. While Grahamstown learned that 'the venerable lady passed away quietly' at her daughter's house in Pietermaritzburg from the local newspaper, ${ }^{1}$ no scientific journal at the Cape, in Britain or in Europe printed an obituary. ${ }^{2}$ She had not published a scientific article for over a decade and spent her last years lapsed into scientific silence in different locations-at Malvern near Durban, in Johannesburg and Pietermaritzburg, and at various places in Albany and elsewhere in the eastern part of the Cape Colony. This was a politically turbulent time in the region, with her death occurring only a few weeks before the South African Republic declared war on Britain and launched what became known as the Second South African War. Relations between Europeans and Africans were equally strained, as they would continue to be for much of the following century. Barber's legacy has been scattered over different archives, museums and collections, and hardly any attention has been paid to them. ${ }^{3}$

Over time, Barber's legacy has been archived in various collections, herbaria, museums and archives. Some objects have been on display in museums. Other sources have been digitised. Yet, rather than preventing Barber-and other historical actors (particularly women and non-Europeans) - from falling into oblivion, these practices increased her marginalisation. Digital platforms, in particular, privilege, silence and filter information and thereby reinforce the hierarchies in archives of written documents. ${ }^{4}$ Tracking down the privileging of metropolitan men's

(C) The Author(s) 2019

T. Hammel, Shaping Natural History and Settler Society, Cambridge Imperial and Post-Colonial Studies Series, https://doi.org/10.1007/978-3-030-22639-8_9 
knowledge requires close readings of museum displays, analogous archival sources and archival as well as commemorative practices.

\section{'Screen Memories' and 'Anachronistic Space' in Museum Displays}

Since the opening of the 1820 Settlers Memorial Museum (today known as the History Museum) in Grahamstown in 1965 next to the Albany Museum (now the Natural Science Museum), the Bowkers and Barber have been commemorated locally for their scientific achievements, to promote an Anglophone South African nationalism. The promoted nationalism started with the building's architecture, which is reminiscent of a Greek temple with its Doric columns at the entrance with a wall with painted engravings of the English St. George's Cross blazon, the Lion Rampant of Scotland, the Welsh Red Dragon, the Irish Saint Patrick's Saltire and one of the ships that brought the British settlers to the Cape. The museum was built to celebrate settler history during a period of concern that the Afrikaner nationalist government would neglect it, and was one of a series of institutions honouring the history of British settlers opened in Grahamstown within a decade of each other, such as the National English Literary Museum (1971) and the 1820 Settlers National Monument (1974). ${ }^{5}$ After the 1820 Settlers Memorial Museum's inauguration, the permanent exhibition remained unaltered for more than three decades.

In 1996, the only recently elected post-apartheid government's White Paper on Arts, Culture and Heritage policy requested museums to transform their displays. ${ }^{6}$ As a provincial museum funded by the new Eastern Cape Department of Sport, Recreation, Arts and Culture, the 1820 Settlers Memorial Museum was consequently required to introduce displays which would reflect these new policies. However, as the curators had shown little interest in Xhosa history and culture before the end of apartheid, the museum held no corresponding collection of objects. In addition, the museum also had to satisfy the demands of the 1820 Settlers' Association, a non-profit organisation with 1200 members who have a keen interest in the museum and finance the genealogist's position there. Combined with scarce funding, this may further explain why it would take ten years for the museum to implement any transformative measures. ${ }^{7}$

In 2007, the institution was renamed 'History Museum'. The permanent 'Settler Gallery' exhibition was retitled the 'Nineteenth-Century 
Lifestyles Gallery'. It was announced that it would be 'renovated to reflect the interaction and changing lifestyles of various groups on the Eastern Cape frontier' at the time. ${ }^{8}$ The gallery walls were repainted in a vivid dark clay- or salmon-coloured earthy backdrop. The glass cases devoted to settler parties and their achievements were rearranged by topic, such as the development of the press in Grahamstown and agricultural industry in Albany. Settler photographs on the pillars were removed in order to create space for new displays that were added on the south side. The museum became part of the Albany Museum Complex that includes five museums in Grahamstown.

At the History Museum, the Bowker Case which includes objects belonging to the 1820 Settler family of Miles and Anna Maria Bowker (née Mitford)-Barber's parents-has ever since the museum's inception been prominently placed in the gallery. ${ }^{9}$ It is unclear whether the artefacts were part of the family estate before being given to the museum. If so, their journey may have led them to a coffee plantation in Kenya with Thomas Holden Bowker's daughter Mary Layard, to her son Raymond Mitford-Barberton in Australia or Gareth Mitford-Barberton in England and then back to Grahamstown. ${ }^{10}$ The grandson of Barber's brother William Monkhouse Bowker, genealogist, big game hunter and farmer Frank Bowker (1871-1942) of Thorn Kloof, and his son Francis donated the Bowker Case to the museum, presumably long before the museum was opened. ${ }^{11}$

Near the Bowker Case, new displays provide information on the history of the amaXhosa living in the area, while immediately next to the Bowker Case are seven black-and-white photographs taken by an anthropologist at the end of the twentieth century. ${ }^{12}$ This display is a classic example of the post-apartheid add-on mode of representation, an 'extend-rather-thanrevise' approach to redress 'the imbalance of the apartheid-era symbolic landscape'. ${ }^{13}$ Instead of transforming the entire exhibition, the curators attempted to insert the local African population into the settler narrative. The overall effect of the exhibition was to historicise settlers, while traditionalising the amaXhosa. With the settler past contained in cases and the African present displayed on clay-coloured walls, this reinvigorated ethnic separation created the impression the two peoples shared no common past. The gallery's name, perhaps unconsciously, implies that twentiethcentury amaXhosa lived in exactly the same way as their ancestors had done in the nineteenth century, thereby depriving them of their historical context and denying them their social evolution. 
A static view is thus presented which is reminiscent of earlier 'noble savage' representations and of 'anachronistic space', a space in which people are presented as contiguous with modernity yet are figured as temporarily out of place. The colonial social hierarchy based on race, which the settlers believed themselves to head and which the museum's curator had been used to portraying throughout apartheid, was projected on the axis of time and thereby naturalised in this display. ${ }^{14}$ The photographs of the Xhosa individuals - that come to represent the amaXhosa-give the impression of predating the objects in the Bowker Case. Their lifestyle in the twentieth century is depicted as that of the past predating that of the 1820 Settlers even though the photographs were taken a century later. ${ }^{15}$

The display therefore does not inform about Xhosa history, but instead is informative on the ways in which history has been produced in this curatorial setting. Visitors gain little insight into hitherto hidden histories through the old and barely modified narratives presented in the museum. Historians have shown that such displays embody the 'history frictions', tensions, debates and conflicts between different communities, each with their own range of interests, perspectives and aims, in places such as Grahamstown. ${ }^{16}$ The curatorial practices were not intended to display these frictions but to leave them concealed from the majority of the visitors' untrained eyes. They are nevertheless visible in the displays, and as such serve as another example of visible concealment.

The display is what Sigmund Freud called 'screen memories', ${ }^{17}$ namely inaccurate reconstructions that obscure what really happened or depict compromises between 'an unconscious recognition of the importance of an experience and an equally unconscious desire not to recognize the experience at all'. ${ }^{18}$ It highlights the importance of colonisation, while at the same time suppressing the destruction of the indigenous population. The complete neglect of histories which preceded the arrival of the 'first settlers' is a feature of the politics of memory generally observed in settler colonial contexts, and evidence of settlers' own 'mnemonic myopia'. ${ }^{19}$

While the permanent exhibition at the History Museum has remained unaltered over the period of my research, a number of temporary exhibitions have attempted to provide additional insights. In 2012, when the town celebrated the bicentenary of its founding, an exhibition with the title 'Assimilate! Resist! Make a Home! Grahamstown's Tumultuous First Fifty Years' was hosted on the museum's second floor. In the exhibition, Rhodes University students of public history told the story of the development of the town from a place of war to one of learning and culture or, as 
their supervisor, the history professor in charge, Julia C. Wells put it, 'from bullets to books'. ${ }^{20}$ 'Our approach is celebrating what we have achieved over two hundred years', commented Wells. ${ }^{21}$ The nineteenth-century scientific community was presented as providing the foundations for the establishment of the renowned Rhodes University in 1904, the fifth university to be founded in South Africa ${ }^{22}$ and the institution under which the museum now falls. From July 2016 to 2018, the social history educator Lindinxiwa Mahlasela was curator. ${ }^{23}$ The opening of two exhibitions 'The amaXhosa Kingdom' and 'The Landscapes of the Eastern Cape' at the History Museum on 9 November 2016, which King Zwelonke Mpendulo C 'Aaah Zwelonke' Sigcawu and many amaXhosa attended, suggested that the museum was transforming. ${ }^{24}$ According to a local newspaper article, 'The amaXhosa Kingdom' 'forms part of a series of Transformation Agenda Exhibitions of the museum'. ${ }^{25}$ The History Museum has decided to 'confront the past'. ${ }^{26}$ The fine artist Gcobisa Zomelele succeeded Mahlasela. ${ }^{27}$ It remains to be seen how this new appointment in Makhanda will bring about further change in the history exhibitions. Digitisation has certainly brought change to archival and research practices.

\section{Digital Plant Collections and Privatisation of KNOWLEDGE}

According to William Henry Harvey's Incoming Plant's book at the Trinity College Dublin Herbarium, the first parcel with dried plants specimens from Mary Elizabeth Barber arrived in October 1859. Until November 1865, when Harvey stopped recording incoming plants due to his deteriorating health, Barber and her brother James Henry Bowker had sent 893 specimens. Today more than 1000 specimens can be traced at Trinity College Dublin Herbarium (TCD). The herbarium sheets are of special importance as they include letter passages, illustrations, which provide insights into their working practices and professional aesthetics. The problem however is that the collection consists of Harvey's selection of letter passages, illustrations and specimens. He glued the most important letter passages and fixed illustrations with a pin on herbarium sheets.

Barber sent much more to Harvey than we find at TCD today. He forwarded bulbs and seeds to the national botanic gardens, Glasnevin, Dublin, and to the Royal Botanic Gardens Kew, London. He traded and exchanged duplicates with the herbarium at the Swedish Museum of Natural History in Stockholm and sent interesting specimens to the co-author of three volumes Flora Capensis 1859-1865 botanist and 
apothecary Otto Wilhelm Sonder in Hamburg. In 1883, Sonder's 300,000 specimens were bought as the nucleus of the Sonder Herbarium at the Royal Botanic Gardens Melbourne, where Barber's specimens are today.

The collection's biography reveals botanists' sense making of their professional selves, their practices and the herbarium. The TCD herbarium was founded in 1840 based on the personal collection of Thomas Coulter. From 1844 to his death in 1866, Harvey was the curator of the herbarium. The next generations of curators have stressed Harvey's hard work mirrored by his accumulation of 100,000 of today's approximately 300,000 specimens. Since 1992, they have heroised Harvey even more, as he achieved this suffering from acute depression. The herbarium then experienced the lack of a curator from Harvey's death in 1866-1869, the move and mixing up of the herbarium bundles in 1882 and again in 1910 to the newly built annex to the School of Botany, where Barber's specimens still are today. These events as well as the fire in the laboratory above the herbarium in 2011 during which the fire brigade flooded parts of the herbarium, certainly led to the loss of specimens, to a slightly confused order and the damage of some parts. These events are all prominent parts of institutional history, in which the herbarium's importance as one of only three university herbaria in Britain and Ireland is stressed.

South African specimens have not been a focus of TCD since Harvey's death, which is why these specimens have not been consulted for decades. As there are many type specimens among them, they are however of vital importance for botanists. This as well as the wish to raise the herbarium's international importance encouraged John Parnell, the herbarium's current curator, to take part in an African Plants scanning project of type specimens in 2006. The material in the herbarium was sought to be made more easily accessible and usable for people worldwide and in partial fulfilment of the Herbarium's commitment to data repatriation under the Convention on Biological Diversity. ${ }^{28}$ Imaging has allowed easy access to certain materials such as Harvey's Travelling Sets of Algae, which had never been loaned to herbaria as the bound volumes contain historically valuable material of many species and could only be seen by botanists who travelled to Dublin. During nine months, 17,123 type specimens, 70 of which were Barber's, were scanned for The African Plant Initiative, a project launched at a meeting of the Association for the Taxonomic Study of the Flora of Tropical Africa in Addis Ababa in September 2003. These 70 out of Barber's 1000 specimens were selected for their botanical importance. Letters and illustrations that were not on the herbarium sheets were 
not included, as were the specimens glued on newspapers. Thus, much information on botanical practices and on local knowledge and its importance for botany was silenced.

The project was initially funded by the Andrew W. Mellon Foundation. The American private foundation based in New York City has four core areas of interest: (1) humanities, libraries and information technology, (2) museums and art conservation, (3) performing arts, (4) nature conservation. Andrew Mellon (1855-1937) was an American banker, industrialist, art collector and ambassador from the wealthy Pennsylvanian Mellon family. Herbaria worldwide were requested to scan holotype specimens of African plants in order to make them accessible in the digital library Aluka. The holotype (or name-bearing type) is a single specimen after which a species is named. This process of digitisation peaked between 2003 and 2009.

Aluka derives its name from the isiZulu verb ukuluka, meaning 'to weave', and was chosen to reflect the library's 'overarching mission - of joining together in a single place resources from around the world'. Yet for the Oshivambo-speaking Ovambo people in northern Namibia, the word carries the meaning of to 'return' or 'repatriate'. ${ }^{29}$ These two different meanings epitomise the various actors' disparate expectations from the project and the challenges faced in the process. Aluka's mission was to build a space where sources could be accessed openly and easily. The platform consisted of four sections-African Plants, Cultural Heritage, African Cultural Heritage Sites and Landscapes, as well as Struggles for Freedom-which made relevant visual and textual sources available in English, French and Portuguese. African Plants consisted of type specimen images in high resolution, botanical illustrations and art, photographs, notes by European explorers, references and publications on taxonomy. ${ }^{30}$ In 2005 , more than forty herbaria and botanical gardens in Africa, Europe and the US were participating in the project, with researchers enthusiastic about the prospect of no longer having to travel long distances to study specimens. ${ }^{31}$

In 2005, a group of historians and archivists in South Africa who had been involved in the project knew that Mellon-funded JSTOR's longterm goal was for the new digital archives on Aluka to become financially sustainable through licence fees from international institutions and independent researchers to finance ongoing projects. However, African universities and other institutions, they believed, would be granted free access, perhaps to assuage those who were suspicious that the initiative would be 
'yet another North American project designed to appropriate Africa's patrimony and subvert intellectual property rights and national heritage'. ${ }^{32}$ These archivists and historians were eager to make sure that the platform did not result in a research tool for the exclusive benefit of Western scholars and students. They hoped that through digitisation, South Africans would get access to a post-colonial, post-apartheid archive that included the voices which had hitherto been silenced and were now crucial for the emergence of the new nation. Institutions, on the other hand, were concerned that they might lose their international renown if researchers no longer needed to personally visit their repositories. Several institutions even demanded a percentage of the assumed profits as compensation. ${ }^{33}$

In South Africa, there has been a heated debate about 'digitisation as neo-imperialism'. ${ }^{34}$ Scholars involved in Digital Innovation South Africa (DISA) - a non-profit collaborative initiative, which has been funded by the Mellon Foundation since its establishment in 1999 and has had a strong affiliation with Aluka's Struggles for Freedom project-criticised Aluka. They sent a letter to the Council of Higher Education South Africa, an independent statutory body established in 1998, to advise the minister of higher education and training on developing, monitoring and reporting on higher education. ${ }^{35}$ In the letter, they warned universities of the risks of international collaboration and the dangers they faced of losing collections of exceptional value, such as those concerned with indigenous knowledge systems, without receiving fair compensation or reciprocity. ${ }^{36}$ The presidents of the Mellon Foundation and ITHAKA, the umbrella organisation for projects such as JSTOR, ARTSTOR and PORTICO, which provide digitised content to higher education institutions, were shown the letter and felt deeply insulted and alienated. ${ }^{37}$

In 2008, Aluka became part of JSTOR. ${ }^{38}$ The data available under African Plants was thus integrated into JSTOR Plant Science and could henceforth only be accessed by people at institutions with a JSTOR licence. However, herbaria which had already scanned their specimens were granted free access. Photographs on digitisation projects in Nigeria and Senegal were used by JSTOR Plant Science to illustrate their success story and advertise for further digitisation projects in Africa. ${ }^{39}$ In May 2013, JSTOR Plant Science was renamed JSTOR Global Plants. JSTOR clients could now only access miniatures of the high-resolution photographs, and anyone who attempted to view larger versions of the images was faced with an 'access denied to JSTOR Global Plants' message. ${ }^{40}$ 
In October 2013, the programme's 308 partner institutions from 75 countries which had scanned their specimens since 2003 were informed that their licences would expire within 8 days unless they paid a new annual licence fee of up to 3800 US dollars. ${ }^{41}$ Bearing in mind the considerable financial difficulties which even large and state-subsidised institutions such as The Royal Botanic Gardens Kew experienced, ${ }^{42}$ this change in policy saw smaller herbaria with limited financial resources lose their access. Curators at Australian and South African herbaria find this privatisation of knowledge challenging for their daily work as they can no longer refer to the platform. With only a limited number of people now having access to the database, the divide between professional and lay botanists has been reaffirmed. The reason for this change seems to have been the Mellon Foundation's termination of funding for its Conservation and the Environment program (C\&E, 1969-2013). ${ }^{43}$ The subsequent restricted or closed access thereby achieved exactly the opposite of the open resource which the foundation had initially promoted. In contrast, Mellon measures its success in terms of its global collaborations and the 2.5 million images and 450,000 articles which the Global Plants Initiative had brought together. ${ }^{44}$

Aluka's project of digitising letters had started with the Director's Correspondence from the Royal Botanic Gardens Kew. ${ }^{45}$ The metropolitan colonial archive was thus prioritised and reproduced before historical sources from other parts of the world were made accessible. ${ }^{46}$ In the process, sources from men botanists from the North were inevitably also favoured, while the institutions such as the Royal Botanic Gardens Kew, in which these historical actors' information was stored, were in turn further mythologised.

Moreover, the accompanying JSTOR Plants Blog only had two articles in which African countries were mentioned in 2012: one in connection with Livingstone's Zambezi expedition, and one on griots, the string instruments made from calabash, a type of gourd. In the latter blog post, the custom to being buried in baobab trees in West Africa was also mentioned. ${ }^{47}$ Africans allegedly used plants for cultural purposes, while Western naturalists were said to describe them according to botanical standards, thus strengthening the dichotomy between informal and formalised, traditional/cultural and scientific knowledge.

JSTOR Global Plants is one of a number of similar digital archives in the US, including the New York Botanical Garden's Index Herbariorum, 
the San Francisco-based archive.org and the Biodiversity Heritage Library run by the Smithsonian Institute Washington and the Missouri Botanical Garden. Open-access databases, which include the latter two, do not control information flow to the extent which JSTOR does. JSTOR privatises knowledge and, economically driven, reproduces colonial archives and thought patterns. ${ }^{48}$

In reaction to JSTOR Global Plants becoming 'a walled garden', ${ }^{49}$ botanists continue to rely on already-established national or regional digital archives which are openly accessible, such as the Australia's Virtual Herbarium (AVH), which was developed in the late 1990s. ${ }^{50}$ Barber's specimens in Australia form part of the Hamburg-based pharmacist and botanist Otto Wilhelm Sonder's ${ }^{51}$ South African plant collection, which originated in his collaboration with Harvey. ${ }^{52}$ As Sonder grew older, he pondered where to deposit his legacy and decided to find an institution outside of Hamburg, a city which had a reputation for being unscientific. Hamburg's low reputation came from the fact that its scientific institutions received most of their collections from trading companies, such as Joh. Ces. Godeffroy \& Sohn. ${ }^{53}$ In 1870, Sonder offered three cases of specimens to his long-time friend Ferdinand Mueller, Victoria's first government botanist at the National Herbarium of Victoria in Melbourne (MEL) ${ }^{54}$ Mueller immediately started petitioning the Victorian government to finance the purchase of Sonder's collection, an acquisition which duly followed in 1883. In the meantime, Sonder had sold much of his South African material to the Swedish Museum of Natural History in Stockholm in 1857 and some of his Australian specimens to the French botanist Jean Michel Gandoger. It has been suggested that those which he sold to the latter, were duplicates of the specimens which Sonder had set aside for Mueller. ${ }^{55}$ Barber's specimens were among these 250,000330,000 loose dried specimens from all over the world with loose labels in bundles and were housed in the new annex to Melbourne's Botanical Museum, which had been purposefully built for this collection. More than half of today's foreign collection at MEL, which totals 400,000 specimens out of the herbarium's overall tally of 1.4 million specimens, came from Sonder. They include specimens from all major plant groups and from every part of the world ${ }^{56}$ After Mueller's death in 1896, the herbarium suffered from financial difficulties, and turned its focus to agriculturally relevant plants, putting little emphasis on growing its collection. ${ }^{57}$ Sonder's specimens were thus not mounted, and less than $15 \%$ of his collection has been databased. The rest are unknown loose 
specimens of unknown origin with loose labels. These herbarium sheets slumber in their original folders with an intricate system. In contrast, Australian specimens from the Sonder collection have been mounted on archive cards, databased and barcoded with an identifying accession number, ${ }^{58}$ and illustrated by high-resolution images which are accessible on AVH.

Particularly problematic here is that botanists who create digital archives of plants, such as the two examples discussed here, barely collaborate with historians, as they share few common aims and perspectives in their work. However, it is exactly this sort of interdisciplinary collaboration which is needed, especially in the increasingly important context of the digitisation of archives. Recent research on herbarium sheets in the National Herbarium of Victoria in Melbourne has shown how parcels to Ferdinand von Mueller were packed by part-Aboriginal Australians. ${ }^{59}$

If information on non-European or women botanists is not part of type specimens' herbarium sheets, it is not digitised. Given that in the second half of the nineteenth century high-acid paper, which gradually changes colour to yellow-brown and decays, was used for herbarium sheets, the information which they contain is likely to be lost even further over time. If these sheets were to be stored in acid-free archival boxes, this process might be slowed down, but only de-acidification, an expensive and cumbersome procedure, can cease the decay. Digitisation thus offers an alternative solution to present botanical research in colonial situations not exclusively as the endeavour of European men.

Barber's vast plant collection at MEL is subsumed behind the memory of two men: Sonder and von Mueller-both Germans. Without any colonial aspirations in Australia and South Africa, German scientists could conduct research across empires. This stands as an example for scientists who could exchange information outside the constraints of their empires, and for an early internationalisation of science, busting the borders of Empire. The Melbourne purchase is an instance of South-South knowledge exchange from one settler nation to another, via Hamburg, which has, however, been made invisible in the digitising of Australia-only herbarium specimens. Striking is the number of German botanists that occurred in leading positions across the British Empire: Otto Sonder in Hamburg, Ferdinand von Mueller in Melbourne, Hermann Becker and Selmar Schoenland in Grahamstown, Hans Schinz in Zurich and South West-Africa. Their network and impact on nineteenth-century botany deserves more attention. 
Yet, most of the digitised sources discussed in this chapter provide a one-sided picture, and digitisation projects need to find a new approach to sources rather than simply reproducing the colonial archive. A 'transformation' of the currently alarming archival practices is thus urgently required.$^{60}$ It is equally essential for historians to engage in critical reflections of the sources and collections which are used.

Fine artists have also critically engaged with the problem of colonial legacies in public spaces or in museums and have most likely been more successful in addressing a wider audience with their concerns than historians. Two examples from Grahamstown from 2012-the year the town celebrated the bicentenary of its foundation-are representative of these endeavours.

The Mauritian-born, South African-based artist Doung Anwar Jahangeer uses art as a platform to raise people's curiosity. During the 2012 Grahamstown National Arts Festival, he staged a public symbolic protest. ${ }^{61}$ In his Making Way Performance - The Other Side With the Matebese Family (2012), he, on the one hand, intervened into the 1820-Settler memorial cult by painting the hands and faces of the Settler Family (1969), a statue created by Barber's grandson Ivan MitfordBarberton. By colouring the settlers with ibomou —a red clay/soil paste used by Xhosa and Zulu women and men in traditional ceremoniesJahangeer wished to welcome history into the present in a ritualistically peaceful manner. ${ }^{62}$ Rather than angrily taking down monuments that remind of an oppressive past, he puts a contemporary mask on the settlers-a ritual that helps to negotiate identity, to Africanise them and symbolically bring them closer to the South African ground, where the soil comes from. On the other hand, his performance was also an intervention into the discourse on post-coloniality, a concept that, according to Jahangeer, does not allow South Africans to move in a continuous way, but constantly forces them 'to negate where they are coming from'. It was thus a 'ritual to welcome the settler family home' and to start conversation about 'issues of identity and post-coloniality' and how South Africans 'got stuck into discourse'. He wished that South Africans acknowledged difference embedded in recognition and dialogue, without anger or hatred. $\mathrm{He}$ described his intervention as an 'act of re-humanising', an 'act that asks for re-humanisation to be entered in what we do'. ${ }^{63}$ With his performance, he called for alternative ways of dealing with the settlers' legacy than silencing through removing artefacts from museum displays and public spaces. 
Also in Grahamstown in 2012, the Cape Town-bred, Johannesburgbased photographer Mikhael Subotzky opened the Standard Bank Young Artist Exhibition by showing his first film Moses and Griffiths (2012) that he made for the occasion-a portrait of two Xhosa guides who give their official tours, as they have done for twenty years and then they make a second tour for the camera where they have decided what part of the history of Grahamstown and their own live stories should be shown. Moses Lamani (1956-2015) worked at the Observatory Museum which is part of the Albany Museum Complex that consists of seven buildings also including: the Natural Sciences Museum, the History Museum, Fort Selwyn, the Old Provost military prison, Drostdy Arch and the Old Priest's House which is leased to the National English Literary Museum. On the rooftop of the Observatory Museum, there is a more than 200-year-old camera obscura which can be steered from within, and the images that resemble photographs can be seen on a round table-like construction. Lamani worked there since 1984. In the tour for tourists, he explains the architecture of the town and its history. In his person tour, he for instance stops at the roundabout and explains: 'If you want to go to the coloured area, you go that way; if you want to go up High Street, you go this way. ${ }^{64}$ Later Lamani shows Makana's Kop, a hill in the townships of Grahamstown where Xhosa leader Makhanda started his attack in 1819. While Makhanda is said to have been a courageous freedom fighter, Moses critically says: 'He was the one who betrayed the Xhosa people [...] he misled a lot of black people during the time of wars. ${ }^{65}$

Lamani's counterpart at the 1820 Settlers Monument is Griffiths Sokuyeka. He is convinced that Grahamstown has become a better place and that much has improved since the end of apartheid. Yet, he is disappointed in how he and his black colleagues have been treated. For instance, when mice nibbled cables and caused a fire in 1994 and destroyed the Settler Monument's auditorium due to a lack of a sprinkler system, the black employees were blamed. Griffiths was so angry at the time that he did no longer want to work there, yet he loved his work and the building and remained. Being blamed hurt in his heart. 'They owe us an apology, what they've done, because treatment was not so good'. ${ }^{66}$

The four different tours are projected on four split screens which demonstrate how these institutional and personal histories conflict and contrast one another. The voices and images result in a complex interwoven narrative. ${ }^{67}$ Doing so, Subotzky succeeds in providing the viewer a sense 
of the two men's past, how they grapple with their experiences under apartheid, how these are representative of Grahamstown's history and how the amaXhosa's experiences over more than the last 200 years are silenced in these heritage institutions that solely celebrate the achievements of British settlers. Through the simultaneous screening of private and public tours, there is an exchange; the histories overlap and there is a new composition of how the history of Grahamstown can be told. Moses and Griffiths (2012) has subsequently been exhibited at Palais de Tokyo in Paris in 2013, at Yale Art Gallery in New Haven in 2014 and Art Unlimited in Basel in 2014. And was eventually acquired by the Tate Modern.

Subotzky is very sensitive to commemorative practices in South Africa and raises awareness for South Africa's haunted pasts in a series of artworks which have attracted attention worldwide. ${ }^{68}$ Subotzky sees himself as an indirect political activist with limited power through his art and photography. He sees himself as a South African artist as his work has a strong social responsibility which every South African has due to the country's history. A responsibility to break fixed social structures. With his images, he wishes to create a window through which viewers can see through these structures, to illuminate what often remains in the dark. For Subotzky, photographing goes into two directions: forward and backwards. An image also allows the viewer to understand the photographer's attitude as well as the perspective of who has been photographed. Subotzky describes this process with the words of Tom Waits' song Eyeball Kid: 'How does he dream, how does he think, when he can't even speak and he can't even blink, we are all lost in the wilderness we're as blind as can be he came down to teach us how to really see.' The viewer changes perspectives, asks questions, sees and better understands the subject in the photograph or film. Subotzky sheds light on memorial practices in South Africa and allows people to tell their stories who have long been silenced and have not become part of historiography. He thereby contributes to transformation and to a younger generation's awareness of past and current social structures as well as the possibilities for change.

Subotzky revealed the marginalisation of Lamani and Sokuyeka's lifestories and history in commemorative practices and heritage institutions in Grahamstown. Similarly, this chapter raised awareness for the complexities of Barber's marginalisation through digitisation and exhibiting of her legacy. Meticulous research in Europe, South Africa and Australia presented puzzle pieces that allowed insights into Barber's life and work and provide 
the statue for the mask - to use Doung Anwar Jahangeer's metaphorthat this book has eventually become. The discursive approach adopted in this study is another alternative of how to deal with the colonial past and to engage with 'ghosts' that have been haunting Makhanda (Grahamstown), South Africa, the history of science and women, as will be discussed in the Conclusion.

\section{Notes}

1. "Personal Brevities", Grocott's Daily Mail, 5 September 1899.

2. Unlike (Trimen 1901, 41); (Bethune-Baker 1916, 231-236).

3. Every collection, as Hamilton shows, has a 'biography', while every individual source comes with a 'backstory' (Hamilton 2011).

4. Since at least 2002, scholars in and on South Africa have been critically examining archives and historical sources to gauge the impact of archival practices on the politics of historiography in the country. See for example: (Hamilton et al. 2002); (Stoler 2002); (Crais 2004); (Lalu 2007).

5. After a fire devastated the 1820 Settlers National Monument in 1994, the South African president Nelson Mandela reinaugurated it in May 1996, reminding those present that it should be a national resource for all the diverse peoples living in South Africa and that it should contribute to national unity and reconciliation. Speech by President Nelson Mandela at the rededication of the 1820 Settlers' Monument Grahamstown, 16 May 1996: http://www.sahistory.org.za/archive/speech-president-nelsonmandela-re-dedication-1 820 -settlers-monument-grahamstown16-may-1996 date accessed 15 September 2016.

6. Department of Arts, Culture, Science and Technology (DACST), White Paper on Arts, Culture and Heritage: All our Legacies, our Common Future, (Pretoria 1996): https://www.dac.gov.za/content/white-paper-arts-culture-and-heritage- 0 , date accessed 13 March 2015.

7. A trope that is used to explain the delay in transformation is the lack of financial means. In the annual report 2009-2010, the Albany Museum manager warned that 'until somebody begins to listen to [their] plights [the] museum will continue to go the way of the dodo bird'. The state subsidy for 2010-2011 (R798 500) would 'go straight into the payment of municipal services leaving nothing for programs let alone transformation'. The manager further claimed that to 'function properly a museum the size of the Albany Museum needs an operational budget of at least $\mathrm{R}$ 10 million a year'. Albany Museum 2009-2010: http://www.ru.ac.za/ media/rhodesuniversity/content/albanymuseum/documents/AM_ ARsml.pdf date accessed 2 February 2015, p. 9. 
8. Figure 5: Exhibition of settler frontier, Albany Museum, Grahamstown. Photo by Premesh Lalu, in: (Witz 2010): 17. According to curator emeritus Fleur Way-Jones, these displays were changed by herself and her assistants, Zene Schwaiba and Vovo Mabutya, in 2009. Way-Jones to Hammel, 2 August 2014.

9. (Mitford-Barberton 1970, 267).

10. For more on the archeological collection displayed see (Hammel 2018).

11. Cornelius Plug, "Bowker, Mr. Francis William Monkhouse (Frank), (mammal collection)", http://www.s2a3.org.za/bio/Biograph_final.php?serial= 320, date accessed 29 December 2016.

12. See Figure 10.2 in (Hammel 2018, 195).

13. (Marschall 2009): 159. Other examples of the same method have been criticised: See for example (Witz et al. 2001; Rassool 2000).

14. (McClintock 2001, 19-20).

15. These exhibits also contain an ethnographic collection consisting of traditional clothes and a case which displays Xhosa beadwork. In 1999, a similar display was curated as part of an exhibition entitled 'Ubuntu, Arts and Cultures of South Africa' by the Musée des Arts d'Afrique et d'Océanie in Paris. This exhibition was also offered to the Tropenmuseum in Amsterdam, but its curator, Paul Farber, found that emphasising the quality of beadwork would be 'very devoid of [the] life, reality and society' out of which they arose. (Faber et al. 2007, 75).

16. (Karp et al. 2006, 2).

17. See for example (Freud 1899; Freud 1953).

18. (Veracini 2010, 90).

19. (Veracini 2010,90,93). The displays are thus revealing in terms of what they conceal and, similarly to other marked sites of initial exploration such as monuments, are typical of the attitude which the Australian historian Inga Clendinnen identifies as what she terms the "“smoke rising from slab huts" narratives'—namely feel-good stories which settlers told their descendants and have subsequently been passed down from generation to generation (Veracini 2010, 90, 93); (Clendinnen 2006, 3-4).

20. (Wells 2014, 72).

21. (Mavundza 2012).

22. Rhodes University was founded after the University of Cape Town (1829), Stellenbosch University (1866), the University of Witwatersrand (1896) and the University of the Free State (1904).

23. Way-Jones is still in her position as genealogist and curator emeritus.

24. See for example: (Maclennan 2016).

25. (Staff Reporter 2016).

26. (Subramaniam 2014, 23).

27. (Cleary 2018). 
28. https://www.cbd.int, date accessed 12 December 2018.

29. (Isaacman et al. 2005, 58).

30. (Masinde and Rajan 2010, 88).

31. (Isaacman et al. 2005): 58. For an example of one of Barber's type specimens from TCD, see: http://plants.jstor.org/stable/10.5555/al.ap. specimen.tcd0001004? searchUri=filter\%3Dname\%26so\%3Dps_group_ by_genus_species $\% 2$ Basc $\% 26$ Query $\% 3$ Dtype $\% 2 \mathrm{Bof} \% 2 \mathrm{Bbrachystelma} \% 2 \mathrm{Bb}$ arberiae, date accessed 30 December 2016.

32. (Isaacman et al. 2005, 59).

33. (Isaacman et al. 2005, 59).

34. (Breckenridge 2014, 509). Most prominently, Pickover and Lalu criticised the process of digitisation. (Pickover 2005); (Pickover 2007), in: (Breckenridge 2014, 509-510). Also see: Pickover 2009, http://wiredspace.wits.ac.za/bitstream/handle/10539/8929/14\%20 Pickover. pdf?sequence $=1$, date accessed 30 December 2016; (Lalu 2007, 34). In 2014, archivist Michele Pickover described Aluka as having 'an intellectual architecture which is declining into an awkward one-dimensional repression/resistance narrative mainly aimed at an undergraduate studies audience in the USA'. She criticised the project for contributing to the existing dissatisfaction among South African archivists, historians, intellectuals and activists with the 'South-North flow of information' and the portrayal of Africans as consumers rather than producers of knowledge. Also problematic for her is that digitisation demands funding, and that the selection of sources is therefore 'rooted in neo-colonial and patriarchal arrangements, thereby excluding marginal voices and contestations of a colonial, popular or superficial past' (Pickover 2014, 10, 15). In response, the historian Keith Breckenridge from Wits Institute for Social and Economic Research, University of the Witwatersrand, has argued that the Aluka-DISA debate, which he characterises as 'unhelpful', brought digitisation projects in South Africa to a halt between 2009 and 2014 (Breckenridge 2014, 502). He celebrates digitisation as a significant achievement towards overcoming the archive's typical role as an 'instantiation of the state's interest in history'. According to his argumentation, digitisation projects on a transnational scale can help to defeat the near monopoly on knowledge accumulation held by state-funded and/or ex-colonial archives, while any obstacles along the way arise due to technological difficulties, such as high costs involved in producing high-resolution master images, which require vast disk space. Breckenridge also sees the policing of ownership, authenticity and reputability for provenance as technological challenges (Breckenridge 2014, 514, 518-519). While I clearly see the benefits of digital archives and hope new projects are going to fulfil Lalu and Pickover's 
criteria, I do not agree with Breckenridge that the problems that have hitherto been faced were of a mere technological nature. I see Breckenridge's article as an attempt at mediating between his critical colleagues and potential project funders in the North.

35. See for example: http://www.che.ac.za/about/overview_and_mandate/ mandate, date accessed 30 December 2016.

36. Heather Edwards and Dale Peters, 'Brief to HESA', 30 June 2006, DISA Collection, Historical Papers, Wits University, quoted in: (Breckenridge 2014, 509).

37. (Breckenridge 2014, 509).

38. http://www.aluka.org/page/about/historyMission.jsp, date accessed 6 June 2014; no longer accessible.

39. See for example JSTOR workshop with exclusively male participants at Bayero University, Nigeria. Wise Initiative, The WISE Awards, JSTOR Plant Science and the Global Plants Initiative: http://www.wise-qatar. org/jstor-plant-science-and-global-plants-initiative-united-states-of-america, last accessed 30 November 2016. () JSTOR Plant Science. And Global Plants Initiative training session at I.F.A.N., Institute Fondamental d'Afrique Noire or African Institute of Basic research, in Dakar, Senegal. http://www.wise-qatar.org/jstor-plant-science-and-global-plants-initiative-united-states-of-america, last accessed 30 November 2016. (C) JSTOR Plant Science.

40. See for example http://plants.jstor.org/stable/10.5555/al.ap.specimen. tcd0001004? searchUri=filter\%3Dname\%26so\%3Dps_group_by_genus_ species\%2Basc\%26Query\%3Dtype\%2Bof\%2Bbrachystelma\%2Bbarberiae, date accessed 30 December 2016.

41. A botanist and curator of a herbarium in South Africa to Hammel, and the email the partner institutions received from JSTOR Global Plants, 5 November 2013: http://about.jstor.org/content/global-plants-formerly-jstor-plant-science, date accessed 7 June 2014; no longer accessible.

42. See for example: "Kew Gardens jobs to be axed in $£ 5 \mathrm{~m}$ shortfall", $B B C$ News: http://www.bbc.com/news/uk-england-london-26821046, 31 March 2014, (C) BBC, date accessed 8 June 2014; Ian Sample, Alice Bell, "Budget cuts threaten Kew Gardens' world-class status", The Guardian, 24 April 2014, http://www.theguardian.com/lifeandstyle/2014/ apr/24/budget-cuts-threaten-kew-gardens-world-class-status, date accessed 8 June 2014.

43. See for example: William Robertson, IV, "2013 Annual Report: Conservation and the Environment: A Brief Retrospective", https://mellon.org/about/annual-reports/2013-conservation-and-environmentbriefretrospect/, June 2014, date accessed 30 December 2016. 
44. http://www.mellon.org/grant_programs/programs/conservation (c) 2013 The Andrew W. Mellon Foundation, date accessed 7 November 2013, no longer accessible for people without login. Tanja Hammel, "The Power of Selection in Archiving Processes", 5th African History Day: Archives: Methods and Sources, Basler Afrika Bibliographien, 9 November 2013; Hammel 2013.

45. See for example (Svensson 2015).

46. Kat Harrington, "Celebrating the Launch of JSTOR Global Plants", 23 May 2013,

http://www.kew.org/discover/blogs/celebrating-launch-jstor-globalplants, date accessed 7 November

2013.

47. http://jstorplants.org/page/4/, date accessed 7 November 2013; no longer available; http://jstorplants.org/2012/04/15/griots-and-baobabs-an-intersection-of-plant-science-and-cultural-heritage $/$, date accessed 7 November 2013; no longer available.

48. There is little information available on this issue apart from articles by JSTOR employees, such as: (Masinde and Rajan 2010).

49. (Breckenridge 2014, 511).

50. Government of South Australia, Department of Environment, Water and Natural Resources, "Australia's Virtual Herbarium", https://www.environment.sa.gov.au/Science/Science_research/State_Herbarium/ Resources/Australias_Virtual_Herbarium, date accessed 30 December 2016.

51. (Sadebeck 1882).

52. See for example (William H. Harvey and Sonder 1859; William Henry Harvey and Sonder 1861; William Henry Harvey and Sonder 1864).

53. See for example (Hücking and Launer 1986); (Kranz 2016).

54. (Short 1990, 8).

55. (Nordenstam 1980).

56. "Otto Sonder Herbarium": http://www.rbg.vic.gov.au/science/herbarium-and-resources/national-herbarium-of-victoria/otto-sonder-herbarium, date accessed 10 August 2014.

57. (Gallagher 2007, 275).

58. Communication with Catharine Gallagher, coordinator, curation National Herbarium of Victoria, Melbourne, June 2014.

59. These include Lucy and Thomas Webb, Lucy Eades and women who collected the plants for which the German-born, Australian-based botanist Ferdinand Mueller achieved scientific fame (Maroske 2014, 74-75, 85); also see: (Vaughan and Maroske 2014); (Olsen 2013).

60. (de Certeau 1988, 75). More projects which raise awareness for racial inequalities in the humanities as well as in the archival process are needed, 
similar to Londa Schiebinger's project Gendered Innovations in Science, Health and Medicine, Engineering, and Environment does for gender inequalities: http://genderedinnovations.stanford.edu/what-is-gendered-innovations.html, date accessed 31 December 2016.

61. See for example: http://www.dala.org.za/dala_doung.html, date accessed 17 December 2016.

62. Excerpt from 'Walking The Other Side: Doung Anwar Jahangeer' by Ruth Simbao in Third Text 27:3, https://www.ru.ac.za/ruthsimbao/exhibitionsperformances/theothersidewiththematebesefamily/, date accessed 15 September 2016.

63. Ruth Simbao, Doung Anwar Jahangeer: The Other Side with the Matebese Family for Making Way, https://vimeo.com/52453783, date accessed 2 March 2019.

64. (Subotzky 2012, 110, also see 87).

65. (Subotzky 2012, 109).

66. (Subotzky 2012, 160).

67. Subotzky, Moses and Griffiths, see: http://www.subotzkystudio.com/ works/moses-and-griffiths/, date accessed 26 March 2015; For a blog post by two of my students in the course 'Productions of Histories in South Africa', Spring Term 2016, University of Basel, see: Julia Streicher, Fiona Hefti: Michael Subotzkys Kunst als Mittel der Geschichtserzählung, http://sahistoriesbasel.ch/uncategorized/mikhael-subotzkys-kunst-alsmittel-der-geschichtserzaehlung/date accessed 21 September 2016; (Subotzky 2012).

68. Mikhael Subotzky, Sticky-tape Transfer 01, Haunted Memories, 2014, Pigment inks, dirt and J-Lar tape on cotton paper, $290 \times 240 \mathrm{~cm}$ : https:// www.artbasel.com/catalog/artwork/12566? blLocaleCode=zh_CN, date accessed 27 March 2015. Another artwork is WYE (2016), an intersecting and mesmerising three channel, immersive video presentation. WYE-the phonetically spelt Old English for the letter y whose shape was used, for instance, in railroad construction-is an imaginary cartographic and temporal triangle which spans three temporalities (nineteenth-century colonial history, an ambivalent and traumatic present day, and an imagined dystopic future) and three disparate colonial experiences: English, Australian and South African. The first film focuses on Feio, an Australian psychoanthropologist from the future who has travelled to the east coast of South Africa to study Craig Hare, a metal detectorist from our present day. The second film revolves around Craig Hare who seeks to connect with the remote, incomprehensible landscape, but also experiences a latent colonial desire to exert control over it. The third film focuses on James T. Lethbridge, the 1820 settler transplanted from England to South Africa. Subotzky thereby problematises the shortcomings of anthropology as study and dis- 
course, its contexts of domination and privilege, through his characters' misunderstandings and misrepresentations. See http://www.subotzkystudio.com/works/wye-text/; http://sherman-scaf.org.au/video/mikhaelsubotzky/ date accessed 6 March 2019.

\section{REFERENCES}

Bethune-Baker, George T. 1916. Obituary, "Roland Trimen, F.R.S". The Entomologists' Record and Journal of Variation XXVIII: 231-236.

Breckenridge, Keith. 2014. The Politics of the Parallel Archive: Digital Imperialism and the Future of Record-Keeping in the Age of Digital Reproduction. Journal of Southern African Studies 40: 499-519.

Cleary, Kathryn. 2018. New Curators Bring Bright Futures for Museums. Grocott's Mail, November 19.

Clendinnen, Inga. 2006. The History Question: Who Owns the Past? Quarterly Essay 23: 1-72.

Crais, Clifton C. 2004. The Politics of Evil. Cambridge: Cambridge University Press.

de Certeau, Michel. 1988. The Writing of History. New York: Columbia University Press.

Faber, Paul, Ciraj Rassool, and Leslie Witz. 2007. South African Family Stories: Reflections on an Experiment in Exhibition Making. Amsterdam: Royal Tropical Institute.

Freud, Sigmund. 1899. Über Kindheits- und Deckerinnerungen. Monatsschrift für Psychiatrie und Neurologie 18: 285-310.

—. 1953. Über Deckerinnerungen. In Gesammelte Werke, vol. 1, 531-554. Frankfurt a.M.: S. Fischer Verlag.

Gallagher, Catherine. 2007. Notes on the Early History of the Collections of the National Herbarium of Victoria. In Through the Eyes of Goyder, Master Planner, ed. Anne McArthur, 274-275. Adelaide: Kanawinka Writers and Historians Inc.

Hamilton, Carolyn. 2011. Backstory, Biography and the Life of the James Stuart Archive. History in Africa 38: 319-341.

Hamilton, Carolyn, Verne Harris, Michele Pickover, Graeme Reid, Razia Saleh, and Jane Taylor, eds. 2002. Refiguring the Archive. Cape Town: David Philip Publishers.

Hammel, Tanja. 2018. The Politics and Production of History on the Birth of Archaeology at the Cape (1827-2015). In Science, Africa and Europe Processing Information and Creating Knowledge, ed. Martin Lengwiler, Nigel Penn, and Patrick Harries, 187-207. Abingdon-on-Thames: Routledge.

Harvey, William H., and Otto Wilhelm Sonder. 1859. Flora Capensis: Being a Systematic Description of the Plants of the Cape Colony, Caffraria, and Port Natal (and Neighbouring Territories). Vol. 1. 3 vols. Dublin/Cape Town: Hodges Smith and Co./A. S. Robertson. 
Harvey, William Henry, and Otto Wilhelm Sonder. 1861. Flora Capensis: Being a Systematic Description of the Plants of the Cape Colony, Caffraria, and Port Natal (and Neighbouring Territories). Vol. 2. 3 vols. Dublin/Cape Town: Hodges, Smith and Co./A. S. Robertson.

- 1864. Flora Capensis: Being a Systematic Description of the Plants of the Cape Colony, Caffraria, and Port Natal (and Neighbouring Territories), 3 vols., (Dublin: Hodges, Smith, and Co./Cape Town: A. S. Robertson, 1859-1860; 1861-1862, 1864-1865). Vol. 3. 3 vols. Dublin/Cape Town: Hodges, Smith and Co./A. S. Robertson.

Hücking, Renate, and Ekkehard Launer. 1986. Aus Menschen Neger machen: Wie sich das Handelshaus Woermann an Afrika entwickelt hat. Hamburg: Galgenberg.

Isaacman, Allen, Premesh Lalu, and Tom Nygren. 2005. Digitisation, History, and the Making of a Postcolonial Archive of Southern African Liberation Struggles: The Aluka Project. Africa Today 52: 55-77.

Karp, Ivan, Corinne A. Kratz, Lynn Szwaja, and Tomas Ybarra-Frausto. 2006. Museum Frictions: Public Cultures/Global Transformations. In Durham. London: Duke University Press.

Kranz, Gabriele. 2016. Hamburg's Botanical Museum and German Colonialism: Nature in the Hands of Science, Commerce and Political Power. In The Politics of Nature and Science in Southern Africa, ed. Maano Ramutsindela, Giorgio Miescher, and Melanie Boehi, 59-86. Basel: Basler Afrika Bibliographien.

Lalu, Premesh. 2007. The Virtual Stampede for Africa: Digitisation, Postcoloniality and Archives of the Liberation Struggles in Southern Africa. Innovations 34: 28-44.

Maclennan, Sue. 2016. Young Poets Perform for King of amaXhosa. Grocott's Mail, November 16.

Maroske, Sara. 2014. A Taste for Botanic Science': Ferdinand Mueller's Female Collectors and the History of Australian Botany. Muelleria 32: 72-91.

Marschall, Sabine. 2009. Symbols of Reconciliation or Instruments of Division? A Critical Look at New Monuments in South Africa. In Culture and Belonging in Divided Societies: Contestation and Symbolic Landscapes, ed. Marc Howard Ross, 151-175. Philadelphia: University of Pennsylvania Press.

Masinde, Siro, and Rahim S. Rajan. 2010. Aluka: Developing Digital Scholarly Collections from and About Africa. Africa Media Review 18: 85-93.

Mavundza, Bombi. 2012. 100 Year Celebration 100 Years Later. Grocott's Mail, August 30.

McClintock, Anne. 2001. Double Crossings: Madness, Sexuality and Imperialism. In The 2000 Garnett Sedgewick Memorial Lecture. Vancouver: Ronsdale Press.

Mitford-Barberton, Ivan. 1970. Comdt. Holden Bowker. An 1820 Settler Book Including Unpublished Records of the Frontier Wars. Cape Town/Pretoria: Human and Rousseau. 
Nordenstam, Bertil. 1980. The Herbaria of Lehmann and Sonder in Stockholm, with Special Reference to the Ecklon and Zeyher Collection. Taxon 29:279-291. Olsen, Penny. 2013. Collecting Ladies: Ferdinand von Mueller and Women Botanical Artists. Canberra: National Library of Australia.

Pickover, Michele. 2005. Negotiations, Contestations and Fabrications: The Politics of Archives in South Africa Ten Years After Democracy. Innovations 40: 1-11.

- 2007. The DISA Project. Packaging South African Heritage as a Continuing Resource: Content, Access, Ownership and Ideology. In World Library and Information Congress, Durban.

—. 2009. Contestations, Ownership, Access and Ideology: Policy Development Challenges for the Digitization of African Heritage and Liberation Archives. In First International Conference on African Digital Libraries and Archives (ICADLA-1), Addis Ababa, Ethiopia, 1-3 July 2009, http://wiredspace.wits.ac.za/bitstream/handle/10539/8929/14\%20Pickover.pdf? sequence $=1$. Accessed 30 Dec 2016.

- 2014. Patrimony, Power and Politics: Selecting, Constructing and Preserving Digital Heritage Content in South Africa and Africa. IFLA: 1-17. http://library.ifla.org/1023.

Rassool, Ciraj. 2000. The Rise of Heritage and the Reconstitution of History in South Africa. Kronos 26: 1-21.

Sadebeck, Richard. 1882. Otto Wilhelm Sonder. Botanisches Centralbaltt 9: 363-367.

Short, P.S. 1990. Politics and the Purchase of Private Herbaria by the National Herbarium of Victoria. In History of Systematic Botany in Australasia. Proceedings of a Symposium Held at the University of Melbourne, 25-27 May 1988, ed. P.S. Short, 5-12. South Yarra: Australian Systematic Botany Society Inc.

Staff Reporter. 2016. AmaXhosa King to Visit Grahamstown. Grocott's Mail, November 4.

Stoler, Ann Laura. 2002. Colonial Archives and the Arts of Governance: On the Content in the Form. In Refiguring the Archive, ed. Carolyn Hamilton, Verne Harris, Michele Pickover, Graeme Reid, Razia Saleh, and Jane Taylor, 83-102. Cape Town: David Philip Publishers.

Subotzky, Mikhael. 2012. Retinal Shift. Göttingen: Gerhard Steidl Verlag.

Subramaniam, Banu. 2014. Ghost Stories for Darwin: The Science of Variation and the Politics of Diversity. Urbana/Chicago/Springfield: University of Illinois Press.

Svensson, Anna. 2015. Global Plants and Digital Letters: Epistemological Implications of Digitising the Directors' Correspondence at the Royal Botanic Gardens, Kew. Environmental Humanities 6: 73-102.

Trimen, Roland. 1901. Obituary Notices, James Henry Bowker. Proceedings of the Linnean Society of London, 113th Session, November 1900 to June 1901, 40-41. 
Vaughan, Alison, and Sara Maroske. 2014. Ferdinand Mueller's Female Plant Collectors: A Biographical Register. Muelleria 32: 91-172.

Veracini, Lorenzo. 2010. Settler Colonialism: A Theoretical Overview. Basingstoke/ New York: Palgrave Macmillan.

Wells, Julia C. 2014. In the Shadow of the Butcher: The Limits to Remembering in Post-Apartheid South Africa. The Public Historian 36: 51-74.

Witz, Leslie. 2010. Museums, Histories and the Dilemmas of Change in PostApartheid South Africa. University of Michigan Working Papers in Museum Studies 3: 1-23.

Witz, Leslie, Gary Minkley, and Ciraj Rassool. 2001. Repackaging the Past for South African Tourism. Daedalus 130: 277-296.

Open Access This chapter is licensed under the terms of the Creative Commons Attribution 4.0 International License (http://creativecommons.org/licenses/ by $/ 4.0 /$ ), which permits use, sharing, adaptation, distribution and reproduction in any medium or format, as long as you give appropriate credit to the original author(s) and the source, provide a link to the Creative Commons licence and indicate if changes were made.

The images or other third party material in this chapter are included in the chapter's Creative Commons licence, unless indicated otherwise in a credit line to the material. If material is not included in the chapter's Creative Commons licence and your intended use is not permitted by statutory regulation or exceeds the permitted use, you will need to obtain permission directly from the copyright holder.

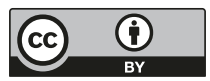

